\title{
PARKINSONISM AND OTHER MOVEMENT DISORDERS IN OUTPATIENTS IN CHRONIC USE OF CINNARIZINE AND FLUNARIZINE
}

\author{
Giorgio Fabiani', Paulo C. Pastro², Carolina Froehner ${ }^{3}$
}

\begin{abstract}
The purpose of this study is to determine the prevalence and the patterns of movement disorders (MD) in outpatients submitted to the chronic use of cinnarizine ( $\mathrm{cz}$ ) or flunarizine ( $\mathrm{fz}$ ), and to establish the main risk factors for MD development. Over a period of 3 months, data were collected from outpatients who were chronic users of $\mathrm{cz}$ or $\mathrm{fz}$ in a municipal health institute. A total of 26 outpatients were included and all of them were submitted to a protocol that included DSM-4 diagnosis criteria for druginduced movement disorders, parkinsonism (PK) and depression. Parkinsonism was diagnosed in $34 \%$ of the patients, PK plus akathisia, PK plus akathisia and bucco-linguo-masticatory syndrome (BLMS), isolated BLMS and dystonia were found in $4 \%$ patients each. Patients with BLMS had the highest median age and the longest average period in which they used the drugs. The affected group, when compared to the nonaffected one, presented with higher rates of depression. This study demonstrates the existence of a direct relationship between the time of use of $\mathrm{cz}$ and $\mathrm{fz}$, the age and the prevalence of PK and other MD. It also suggests that these drugs increase the incidence of depression.
\end{abstract}

KEY WORDS: parkinsonism, drug-induced movement disorders, cinnarizine, flunarizine.

\section{Parkinsonismo e outros distúrbios do movimento em pacientes ambulatoriais sob uso crônico de cinarizina ou flunarizina}

RESUMO - O objetivo deste estudo foi determinar a prevalência e os padrões de distúrbios do movimento (DM) em pacientes ambulatoriais sob uso crônico de cinarizina (cz) ou flunarizina (fz), além de estabelecer os principais fatores de risco para o seu aparecimento. Durante três meses foram coletados dados de pacientes ambulatoriais em uso de cz ou fz. Todos esses pacientes foram submetidos a protocolo pré-estabelecido que incluía critérios diagnósticos do DSM-IV para distúrbios do movimento induzido por drogas e critérios para diagnostico de depressão maior. Parkinsonismo (PK) puro foi diagnosticado em $34 \%$ dos pacientes, PK com acatisia, PK com acatisia e síndrome mastigatória bucolingual (SMBL), SMBL isoladamente e distonia, foram encontrados em $4 \%$ dos pacientes. Os pacientes com SMBL apresentavam a média de idade mais avançada, o maior tempo médio de uso das drogas, configurando-se o grupo de maior risco ao aparecimento dos DM. $O$ grupo dos pacientes com DM apresentou maior incidência de depressão quando comparados com os não afetados. O estudo demonstra uma relação direta entre o tempo de uso da droga, a idade avançada do paciente e o surgimento dos DM. Os resultados também sugerem que estas drogas aumentam a incidência de depressão.

PALAVRAS-CHAVE: parkinsonismo, distúrbios do movimento induzido por drogas, cinarizina, flunarizina.

Drug - induced parkinsonism (DIP) is the most common cause of symptomatic parkinsonism (PK) ${ }^{1-3}$. It can be caused by any drug that inhibits dopamine metabolism ${ }^{1-3}$. Neuroleptic drugs are the best-recognized offending agents ${ }^{2}$. Cinnarizine (CZ) and flunarizine (FZ) represent one of the most common causes of DIP in many countries where they are prescribed $^{1-6}$. Melo-Souza first reported the occurrence of PK and depression secondary to $\mathrm{fz}^{3}$. Afterwards, Martí-Massó and Chouza, in addition to many oth- ers, have reported patients with PK, tardive dyskinesia, akathisia and depression induced by $\mathrm{fz}$ or $\mathrm{Cz}^{4-10}$. Cinnarizine is a selective calcium entry channel blocker and is also neuroleptic - simile, and has antihistaminic, antiserotoninergic and antidopaminergic activity. Flunarizine is a di-fluorinated derivative of $c z$, being 2.5 to 15 times more potent than $^{2,5}$. Both $\mathrm{Cz}$ drugs are widely prescribed for vertigo, migraine prophylaxis and blood flow disturbances, especially in Europe and South Ame-

\footnotetext{
${ }^{1}$ Clinical Neurologist at NEUROVITA - Hospital VITA de Curitiba, PR, Brazil; ${ }^{2}$ Assistant Professor of Internal Medicine, Faculdade Evangélica de Medicina do Paraná, Curitiba PR, Brasil (FEMPAR); ${ }^{3}$ Medical student at FEMPAR.
}

Received 24 November 2003, received in final form 25 March 2004. Accepted 14 May 2004.

Dr. Giorgio Fabiani - Rua José de Alencar $1307 / 53$ - 80040-070 Curitiba PR - Brasil. E-mail: giorgiofabiani@aol.com 
rica ${ }^{1,2,4-10}$. Gimenez-Roldaan demonstrated cinnarizine-induced parkinsonism after a mean exposure of $4( \pm 4)$ years ${ }^{6}$. Careful epidemiologic data are still lacking. Some patients while using these drugs develop many side effects, including drowsiness, asthenia, depression and extrapyramidal side effects or movement disorders (MD) such as PK, dystonia, akathisia, and tardive dyskinesia. Depression is a very common side effect of these drugs ${ }^{1-6,8-10}$. The pathophysiologic mechanisms underlying $\mathrm{fz} / \mathrm{cz}$ induced movement disorders remain uncertain, but the most likely is their ability to block D2-receptors, like many neuroleptic drugs $s^{2,5,7,11,12}$. There is also the potential contribution of pre-existing basal ganglia dysfunction due to aging and vascular disease $\mathrm{e}^{1,2,6,7,11}$. The genetic risk-factors should not be ignored ${ }^{13}$.

This study aimed to determine the prevalence and the patterns of parkinsonism and other movement disorders, in addition to establish the depression rates in outpatients submitted to chronic use of cinnarizine or flunarizine, and to establish the main risk factors for its development, correlating them with the results found in the literature.

\section{METHOD}

A retrospective study (point prevalence study) was performed at a municipal health-institute in the course of 3 months; we evaluated 26 outpatients that were taking, for any reason, $\mathrm{cz}$ or $\mathrm{fz}$, and complied with the inclusion criteria.

The inclusion criteria were: to have been using $\mathrm{cz}$ or $\mathrm{fz}$ for at least one month; onset of the symptoms of PK/ MD (if applicable) after the beginning of the therapy with these drugs.

The exclusion criteria were: patients simultaneously using other drugs that may be responsible for the development of the MD; patients using the drugs for less than one month; presence of any other factor that can explain the MD.

The MD were diagnosed and classified according to our pre-established protocol based on the diagnosis criteria established in DSM-IV for drug-induced movement disorders (including the tardive syndromes), drug-induced parkinsonism, and depression ${ }^{14}$. The protocol included questions about past history of essential tremor and $\mathrm{PK}$, in the patient and family. All the patients were also submitted to the Hoehn-Yahr and Simpson Angus Scale (SAS) for rating the severity of the PK/MD ${ }^{15,16}$.

All the patients gave a verbal consent to participate in this study. The study was approved and authorized by the Araucaria Municipal Health Council. We only collected data from outpatients that were already using these drugs and we neither started nor induced the use of any of the drugs by any of them.

\section{RESULTS}

We evaluated 26 outpatients, most of whom were female, totalizing 21 patients or $81 \%$, and only 5 patients or $19 \%$ were males. Regarding the diagnosis of the movement disorders, we found 13 patients to be completely normal or $50 \%$ of the sample, 9 patients met the diagnosis criteria for parkinsonism; one patient reported bucco-linguo- masticatory syndrome (BLMS) plus PK; one reported BLMS plus PK and akathisia, one reported BLMS only and one reported dystonia. The data are summarized on Figure 1. The mean age of our sample was 62.3 years (57.4 years for the affected group and 67.2 years for the non-affected one). Figure 2 shows the mean time of use of the drugs prior to the onset of the symptoms and the mean time of the treatment (in months). The mean scores found in the SAS were 11.1 for the patients with PK and the Hoehn and Yahr scale's mean score was 2.3 for the affected patients. None of the patients reported a past history of essential tremor or previous diagnosis of PK. Likewise, none of the patients, except for one with drug-induced parkinsonism, reported a positive familial history of PK; this is strictly different from the most important study ${ }^{6}$. Nine patients met the DSM-IV diagnosis criteria for major depression. Most of them, 7 patients or $77.8 \%$, reported its occurrence simultaneously with PK alone or in association with BLMS plus akathisia, or with BLMS as it occurred in one patient. The average doses of $\mathrm{cz}$ or $\mathrm{fz}$ the affected patients were using were $72.1 \mathrm{mg}$ of cinnarizine and $11,2 \mathrm{mg}$ of flunarizine.

All the patients with BLMS were women and were diagnosed to be suffering with depression. They also had the highest mean age, with an average of 78.3 years, and also reported the longest time on drug use, with an average of 48 months. The most important data from this group of patients

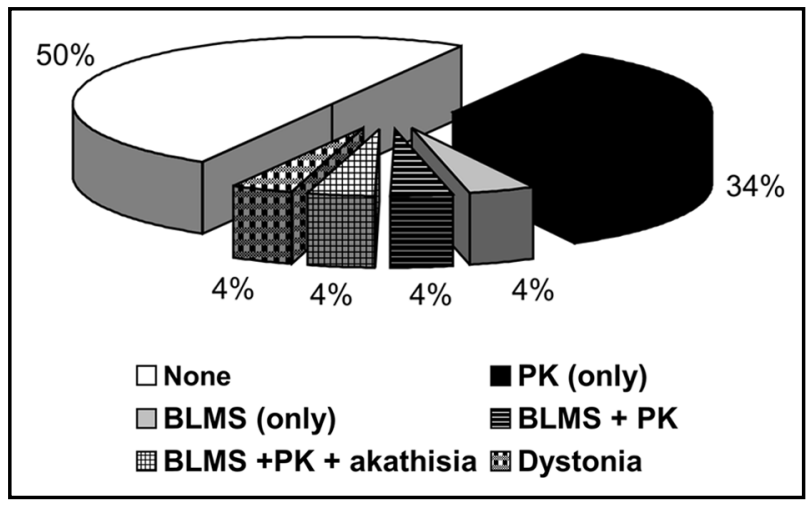

Fig 1. Movement disorders observed in 26 patients. 


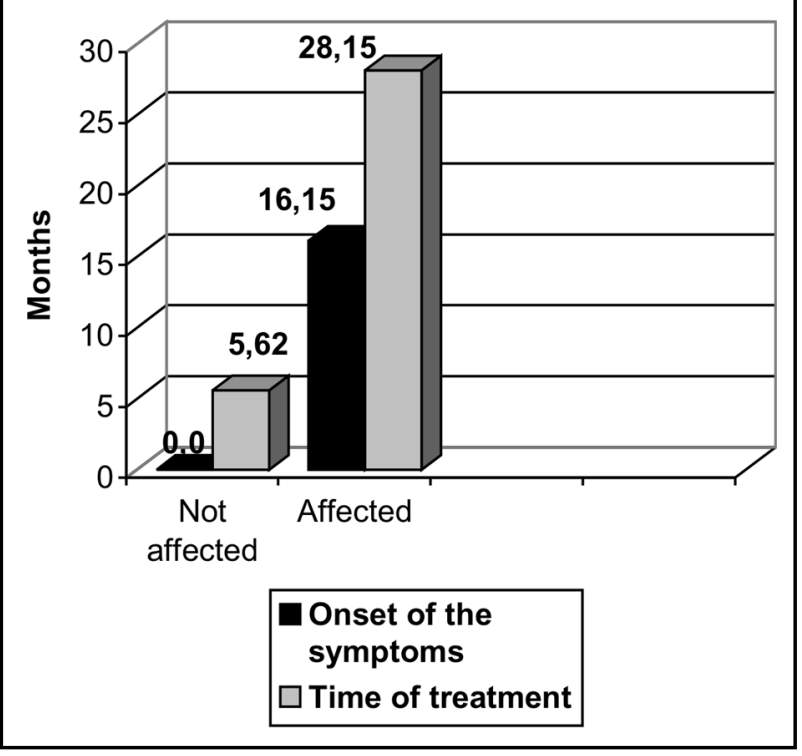

Fig 2. Mean time of use of the drugs prior to the onset of the symptoms and the mean time of the treatment (in months).

are summarized on Table 1. On Table 2, the main data from all the patients of this study have been summarized. All the patients studied were using the drugs longer than six months.

\section{DISCUSSION}

Drug induced movement disorders (DIMD) are often unnoticed by general practitioners, mainly when they do not occur as a result of the use of dopaminergic blockers or neuroleptic drugs. The MD resulting from the chronic use of cinnarizine and flunarizine develop slowly and non-neurologists do not pay much attention to their side effects. Many widely prescribed drugs can also be responsible for or may be responsible for the DIMD 2,7,11,17. Among the most common ones we can mention the antiemetics, drugs for dizziness (calcium chan- nel blockers) and the neuroleptic drugs ${ }^{1,25,7,-9,17}$. Neuroleptics can induce a variety of MD due to changes in the dopaminergic pathways and it is the second most frequent cause of parkinsonism ${ }^{7,17,18}$. The pathophysiology of these disorders is almost always related to disturbances in the dopamine pathways, mainly by blocking the D2-receptors, like many neuroleptic drugs $s^{1,2,4,5,7,11,19}$. Brucke et al. demonstrated that studying patients examined with single-photon emission tomography using $\{123\}$ iodobenzamide as a ligand and it showed the D2 receptor blockade by $\mathrm{Cz}$ and $\mathrm{fz}^{19}$. Both drugs also inhibit the Mg ATP-dependent generation of a transmembrane proton electrochemical gradients in chromaffin granule ghosts, reduce $3 \mathrm{H}$-spiperone binding to bovine striatal membranes and $3 \mathrm{H}-$ dopamine uptake. An idiosyncratic vulnerability or hypersensitivity may also play a contributory role. Likewise, the genetic risk factors should not be ignored ${ }^{2,5-7,11,13}$. It is possible to start a sub-clinical PK while any of these drugs is being used ${ }^{2}$. Young patients show a tendency to acute reactions, mainly the dystonic ones; older patients, on the contrary, more often show tardive or chronic reactions. Parkinsonism is by far the most common MD encountered in these patients. There is an increased risk for women to develop drug-induced PK and other $\mathrm{MD}^{18,20}$.

Negrotti et al. studied the natural course of calcium-entry blocker-induced parkinsonism in 13 elderly patients previously exposed to $c z$ or $f z^{1,13}$. None of the patients showed full recovery from the extrapyramidal signs, indicating that the longterm prognosis is less benign than previously reported. The majority of the affected patients will not present remission of the symptoms after the withdrawal of the drugs. Some of the patients will continue to show PK and others will develop tardive dyskinesia or another $\mathrm{MD}^{1,4,12,13,18}$.

Table 1. Patients with BLMS (main features).

\begin{tabular}{cccccccc}
\hline Gender & $\begin{array}{c}\text { Time of use } \\
\text { (months) }\end{array}$ & $\begin{array}{c}\text { Onset after } \\
\text { (months) }\end{array}$ & SAS & $\begin{array}{c}\text { Age } \\
\text { (years) }\end{array}$ & $\begin{array}{c}\text { PK } \\
(2)\end{array}$ & $\begin{array}{c}\text { Depression } \\
\text { (3) }\end{array}$ & $\begin{array}{c}\text { Akathisia } \\
(1)\end{array}$ \\
\hline $\mathrm{F}$ & 60 & 48 & 12 & 87 & + & + \\
$\mathrm{F}$ & 36 & 30 & 17 & 76 & + & + & + \\
$\mathrm{M}$ & 48 & 36 & 1 & 72 & - & \\
Average & 48 & 38 & 10 & 78.3 & & - \\
Months & & & & & & \\
\hline
\end{tabular}

F, female; M, male; SAS, Simpson Angus Scale. 
Table 2. Summary of the most important data on the patients studied.

\begin{tabular}{|c|c|c|c|c|c|c|c|c|c|c|}
\hline $\begin{array}{l}\text { Gender/ } \\
\text { years }\end{array}$ & $\begin{array}{c}\mathrm{FZ} \\
(\mathrm{mg})\end{array}$ & $\begin{array}{c}C Z \\
(\mathrm{mg})\end{array}$ & None & PK & BLMS & $\begin{array}{l}\text { BLMS } \\
+\mathrm{PK}\end{array}$ & $\begin{array}{c}\text { BLMS } \\
+\mathrm{PK}+\mathrm{AK}\end{array}$ & Depression & Dystonia & TT \\
\hline $\mathrm{F} / 59$ & 10 & 0 & No & Yes & No & No & No & No & No & 36 \\
\hline M/65 & 0 & 75 & No & Yes & No & No & No & No & No & 18 \\
\hline $\mathrm{F} / 61$ & 10 & 75 & No & No & No & No & No & No & Yes & 6 \\
\hline $\mathrm{M} / 59$ & 0 & 75 & No & Yes & No & No & No & No & No & 24 \\
\hline F/64 & 10 & 0 & No & Yes & No & No & No & No & No & 6 \\
\hline $\mathrm{F} / 53$ & 10 & 75 & Yes & No & No & No & No & No & No & 6 \\
\hline $\mathrm{F} / 61$ & 0 & 75 & Yes & No & No & No & No & No & No & 12 \\
\hline F/85 & 0 & 75 & Yes & No & No & No & No & No & No & 6 \\
\hline F/63 & 0 & 75 & Yes & No & No & No & No & No & No & 6 \\
\hline$F / 37$ & 0 & 75 & Yes & No & No & No & No & No & No & 2 \\
\hline $\mathrm{M} / 59$ & 0 & 75 & Yes & No & No & No & No & No & No & 3 \\
\hline F/67 & 0 & 75 & Yes & No & No & No & No & No & No & 2 \\
\hline$F / 63$ & 0 & 75 & Yes & No & No & No & No & No & No & 12 \\
\hline $\mathrm{F} / 55$ & 0 & 75 & Yes & No & No & No & No & No & No & 12 \\
\hline$M / 64$ & 0 & 75 & Yes & No & No & No & No & No & No & 3 \\
\hline $\mathrm{F} / 51$ & 10 & 75 & Yes & No & No & No & No & No & No & 6 \\
\hline $\mathrm{F} / 44$ & 0 & 75 & Yes & No & No & No & No & No & No & 2 \\
\hline F/87 & 10 & 75 & No & Yes & No & No & Yes & Yes & No & 60 \\
\hline $\mathrm{F} / 72$ & 0 & 75 & No & Yes & No & No & No & Yes & No & 12 \\
\hline $\mathrm{F} / 76$ & 10 & 75 & No & Yes & No & Yes & No & Yes & No & 36 \\
\hline $\mathrm{F} / 50$ & 20 & 0 & No & Yes & No & No & No & Yes & No & 24 \\
\hline M/72 & 10 & 0 & No & No & Yes & No & No & Yes & No & 48 \\
\hline F/66 & 10 & 50 & No & Yes & No & No & No & Yes & No & 24 \\
\hline $\mathrm{F} / 58$ & 0 & 75 & No & Yes & No & No & No & Yes & No & 60 \\
\hline$F / 84$ & 0 & 75 & No & Yes & No & No & No & Yes & No & 12 \\
\hline $\mathrm{F} / 44$ & 0 & 75 & Yes & No & No & No & No & Yes & No & 1 \\
\hline
\end{tabular}

In the present study we didnot have any patient with a past history of essential tremor and only one patient reported a positive familial history of Parkinson's disease, unlike from other studies ${ }^{6}$. The main risk factors for the development of $\mathrm{MD}$ in this study were advancing age over 50 -years old, prolonged use of the drugs, usually more than 6 months. This is similar to the results by Brucke et al. with an average onset of the symptoms after 16 months. This time latency is shorter than the results obtained by Gimenez - Roldan, which demonstrated cinnarizine-induced parkinsonism after a mean exposure of $4( \pm 4)$ years ${ }^{6,19}$. The association of both drugs, $\mathrm{Cz}$ and $\mathrm{fz}$, increased the risk of MD. Only two of the non-affected patients were using both drugs, thus while 4 of the affected patients were using both drugs, indicating that this association really aggravates the problem.

The affected patients showed a higher incidence of depression when compared with the non-af- 
fected ones. This is likely due to the antiserotoninergic and antidopaminergic properties of both drugs ${ }^{2,5}$. The patients with BLMS presented the highest mean age: more than 70 years old, and also reported the longest time of drug use; over 48 months, and the highest prevalence rates of depression, confirming a more severe blockade either by the patient's age or by the longest time of use.

Unfortunately we havenot done the follow-up of the patients, so we cannot establish a final prognosis as to the recovery of the PK and the other MD that were encountered.

\section{REFERENCES}

1. Negrotti A, Calzetti S. A long-term follow-up study of cinnarizine and flunarizine induced parkinsonism. Mov Disord 1997;12:107-110.

2. Micheli F, Pardal MF, Gatto M, et al. Flunarizine and cinnarizineinduced extrapyramidal reactions. Neurology 1987;37:881-884.

3. Melo-Souza SE. Flunarizina, parkinsonismo e depressão. XI Congresso Brasileiro de Neurologia, Goiânia, Goiás, Brasil, 1984. Abstracts.

4 Martí-Massó JF, Carrera N, De La Puente E. Posible parkinsonismo inducido por cinaricina. Medicina Clinica 1985;85:614-616.

5. Chouza C, Scaramelli A, Caamano JL, et al. Parkinsonism, tardive dyskinesia, akathisia and depression induced by flunarizine. Lancet 1986;1:1303-1304.

6. Gimenez-Roldaan S, Mateo D. Cinnarizine-induced parkinsonism: susceptibility related to aging and essential tremor. Clin Neuropharmacol 1991;14:156-164.
7. Marsden CD, Jenner P. The pathophisiology of extra pyramidal side effects of neuroleptic drugs. Phycol Med 1980;10:55-72.

8. Fontanari JL. Efeito colateral da flunarizina: parkinsonismo grave. Arq Neuropsiquiatr 1989;47:352-354.

9. Sa PND, Heinisch LMM. Parkinsonismo induzido pela flunarizina. Arq Neuropsiquiatr 1989;47:471-473.

10. Galhardo I, Coutinho MOM, Albuquerque ES, et al. Parkinsonismo induzido pela flunarizina: a propósito de um caso. Arq Neuropsiquiatr 1993;51:546-548.

11. Gershanik OS. Drug-induced dyskinesias. In Jankovic J J, Tolosa E, (eds). Parkinson's disease \& movement disorders $-4^{\text {th }}$.Ed. Philadelphia: Lippincott Williams \& Wilkins 2002:365-379.

12. Garcia Ruiz PJ, Yebennes G. Jimenes - Jimenez Fj, et al. Parkinsonism associated with calcium channel blockers: a prospective follow-up study. Clin Neuropharmacol 1992;15:19-26.

13. Negrotti A, Calzetti S, Sasso E. Calcium entry-blockers induced parkinsonism: possible role of inherited-susceptibility. Neurotoxicology 1992;13:261-264.

14. American Psychiatric Association: Diagnostic and statistical manual of mental disorders, $4^{\mathrm{TH}}$ ED. Washington, DC: American Psychiatric Association 1994:303-312;693-708.

15. Simpson GM, Lee JH, Zoubok B, Gardos G. A rating scale for tardive dyskinesia. Psychopharmacol 1979;64:171-179.

16. Hoehn MM, Yahr MD. Parkinsonism: onset, progression and mortality. Neurology 1967;17:427-442.

17. Cardoso F. Etiology of parkinsonism in a Brazilian movement disorders clinic. Arq Neuropsiquiatr 1998;56:171-175.

18. Llau ME, Nguyen L, Senard JM, Rascol O, Montastruc JL. Drug-induced parkinsonian syndromes: a 10-year experience at a regional center of pharmaco-vigilance. Rev Neurol 1994;150:757-762.

19. Brucke T, Wober C, Podreka J, et al. D2 receptor blockade by flunarizine and cinnarizine explains extrapyramidal side-effects: a SPECT study. J Cer Blood - Flow Metab 1995;15:513-518

20. Rajput AH. Epidemiology of Parkinson's disease. Can J Neurol Sci $1984 ; 11: 156-159$. 